\title{
HDAC1 wt Allele
}

National Cancer Institute

\section{Source}

National Cancer Institute. HDAC1 wt Allele. NCI Thesaurus. Code C49389.

Human HDAC1 wild-type allele is located within 1p34 and is approximately $42 \mathrm{~kb}$ in length. This allele, which encodes histone deacetylase 1 protein, plays a role in the deacetylation of lysine residues on the $\mathrm{N}$-terminal region of the core histones $(\mathrm{H} 2 \mathrm{~A}$, $\mathrm{H} 2 \mathrm{~B}, \mathrm{H} 3$ and $\mathrm{H} 4)$. 